\title{
이야기 다시 말하기 조건이 취학전 아동의 이야기 다시 말하기 산출의 개선에 미치는 효과
}

문선모(文善模)*

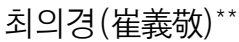

\section{논문 요약}

이 연구는 만 5 세 취학전 아동을 실험참가자로 하여 이야기 다시 말하기 조건이 이야기 다시 말하기 산출의 개선에 미치는 효과를 검증하였다. 실험에는 혼합, 피험자간, 피험자내 설계가 사용되었다. 피험자간 변인은 이 야기 다시 말하기 조건(이야기 다시 말하기 · 이야기 구조기반 이야기 다시 말하기 · 통제)이었으며, 피험자내 변인은 검사시기(사전 - 사후)였다. 준거변인은 이야기 다시 말하기 전체 산출 및 개개 구조요소 산출에서 사후검 사와 사전검사의 차이점수였다. 그 결과, 이야기 다시 말하기를 이야기 지도 수업을 적용하고 함께 이야기 구조 요소에 대한 구체적 단서를 발판으로 제공하여 이야기 구조기반으로 가르치거나 또는 일반적 단서 중심으로 가 르치는 것이 이야기 다시 말하기 방법을 가르치지 않는 것보다 이야기 다시 말하기 전체산출과 해결 구조 요소 산출의 개선에 효과적이었다. 또한 이야기 구조 요소별 산출의 개선은 해결, 배경, 순서, 구성 요소 간에는 유의 한 차이가 없었으나, 이들 4 개 요소는 문제 요소보다 유의하게 높았다. 이런 결과는 이야기 다시 말하기 조건에 관계없이 동일하게 나타났다. 


\section{I. 서론}

\section{1. 문제의 제기}

유아 누리과정의 5 개 영역 중의 하나인 의사소통 영역에서는 다른 사람의 이야기를 관심 있게 듣고 이해하고, 일상생활에서 일어나는 일들을 간단한 문장으로 말하고, 읽어주는 내용에 관심 을 가지고 책읽기에 흥미를 가지며 그리고 말을 글로 나타내는 것에 관심을 보이도록 하는 것을 학습목표로 한다.

아동의 언어능력 발달에서 낱말과 문장 또는 이야기를 듣고 이해하고, 생각과 느낌을 말하기 는 대단히 중요하다. 언어능력은 아동의 거의 모든 생활 측면에서 예를 들면, 긍정적인 또래관 계, 효과적인 커뮤니케이션, 학교에서의 적절한 학습에 중요하다(Spencer, 2009). 아동에게 이야 기책을 읽어주는 과정을 통해 의미가 구성될 수 있다. 즉 아동과 이야기책을 읽어주는 사람 사이 에 서로 의미구성을 교환하는 과정의 상호작용 행동을 통해 의미구성은 향상된다. 이러한 가능 성을 가진 한 방략이 바로 “이야기 다시 말하기(story retelling)”이다(Sisco, 1992). Brown과 Cambourne(1987)는 아동이 쓴 이야기 다시 말하기는 읽고 쓰는 능력의 성장을 평가할 수 있는 수단으로 이용할 수 있다고 했다. 녹음한 이야기 다시 말하기는 아동의 어휘, 언어의 유창성과 복잡성, 이야기의 전개에 대한 이해를 알아 볼 수 있는 한 방법이기도 하다(Genishi \& Dyson, 1984). 이와 같이 이야기 다시 말하기는 여러 가지 교실 적용의 유용성이 크다.

이야기 다시 말하기의 선행연구들에서 행해져온 처치의 구체적인 내용을 살펴보면 주로 세 가지 측면에서 이루어져 왔음을 찾아볼 수 있었다. 첫째, 전형적으로 아동에게 이야기책을 읽어 주면서 “이 책을 보고, 주의 깊게 들어라”고 지시한 다음, 그 이야기의 내용을 모르는 친구에게 이야기하듯 이야기를 다시 말하게 지시한다(예컨대, John, 2001; Morrow, 1985; Westerveld; 2010; Zanowicz, 1996). 이러한 처치는 단순지시 접근으로 볼 수 있다. 둘째, 이야기 다시 말하기 를 할 때 막연한 단순지시보다는 “그리고 그다음에 ..." 등과 같은 막연한 프람프트(예컨대, Cleven, 2005; Tucker, 2001) 또는 “처음에 무엇이 일어났어요?” 등과 같은 발판제공 안내 (scaffolding guidance)를 하는 구체적인 프람프트(예컨대, Greathouse, 1991; Tucker, 2001)가 사 용되기도 했다. 이러한 처치는 단서제시 접근으로 볼 수 있다. 셋째는 이야기 구조 요소를 언급 하여 다시 말하기를 격려하는 연구들이 이루어졌다. 적용된 이야기 구조 요소로 Morrow(1986), $\operatorname{Sisco(1992)ㄴㅡㄴ~ㅂㅐㄱㅕㅇ,~ㅈㅜㅈㅔ,~ㄱㅜㅅㅓㅇ~ㅇㅔㅍㅣㅅㅗㄷㅡ,~ㅎㅐㄱㅕㄹㄹㅗ~ㅂㅜㄴㄹㅠㅎㅏㄴ~ㅂㅏㄴㅁㅕㄴㅇㅔ,~Kuldanek(1998)ㄴㅡㄴ~ㅂㅐㄱㅕㅇ,~ㅁㅜㄴㅈㅔ,~}$ 순서, 결말로 분류했다. 연구자들 간에 분류와 용어는 다소 달랐다. 이러한 처치는 이야기 문법 (story grammar)(구조) 접근으로 볼 수 있다.

위 세 가지 접근법들 중 단순지시 접근은 모호할 수 있어 과연 아동들이 지시대로 잘 수행할 
지 의문이 있으며, 둘째 단서제시 접근은 아동이 이야기 다시 말하기를 잘 할 수 없을 때, 말하기 를 촉진하기 위한 목적으로 이야기 구조 요소를 프람프트 단서로 언급·사용했으나 아동이 이야 기의 구조와의 관련성을 인식하기에는 모호하다는 문제점이 있다. 그런데 이야기 문법(구조) 접 근은 단서제시 접근보다는 다소 구체적이긴 했다. 그렇지만 구조 요소를 다소 반영한 Morrow(1986), Tucker(2001)의 기존 두 연구에서 알 수 있듯이 아동이 이야기 다시 말하기를 잘 할 수 없을 때, 말하기를 촉진하기 위한 목적으로 이야기 구조 요소를 프람프트로 언급하여 사용했을 뿐이었다. 이야기 구조 요소를 인식하도록 강조하여 구체적으로 가르치지는 않았다.

이 연구는 위의 세 접근법들 중 셋째 이야기 문법 접근을 채택하기로 하되, 위에서 지적한 문제점들을 인식하여 개선하기로 했다. 그 개선의 하나로서 먼저 이 연구에서는 이야기 구조에 대한 이해를 높이기 위해 이야기 다시 말하기에 이야기 지도 수업(story map instruction) 접근 을 결합하면 아동이 이야기의 주요 구조 요소에 대해 인식을 더 잘하여 이야기 다시 말하기를 더 잘 산출할 것으로 가정했다. 이러한 처치를 이 연구에서는 구조기반 이야기 다시 말하기 조건 으로 간주했다.

이야기 구조기반은 Mandler와 Johnson(1977), Thorndyke(1977)의 이야기 구조 및 문법 이론 을 바탕으로 했다. 이야기 구조 요소에 대한 분류와 용어는 연구자들마다 다소 달랐으나, 이 연 구에서 채택한 주요 이야기 구조는 배경(등장인물, 시간, 장소), 문제(주제), 구성 에피소드(주요 사건들, 반응, 시도), 해결(결말, 종결, 결과)을 중심으로 했다. 이야기 구조기반 이야기 다시 말하 기 처치에서 아동의 이야기 구조 요소에 대한 인식능력을 높이기 위한 이야기 지도 수업은 Baumann과 Bergeron(1993)의 이야기 지도 수업(story map instruction), Dansereau와 Cross(1990), 문선모·김은수(2001, 2012)의 지식 지도화(knowledge mapping) 등을 참고로 수정 하여 구성했다.

지금까지 선행연구들은 이야기 문법을 중심으로 이야기 구조 자체를 가르치거나 또는 이야기 다시 말하기 자체만을 적용하여 즉, 둘을 분리하여 그 각각의 효과를 검증해왔다. 이와 달리 이 연구의 이야기 구조기반 다시 말하기 조건에서는 두 가지 접근을 함께 결합하여 적용해 그 효과 를 검증하기로 했다. 또한 이야기 구조 요소를 직접적으로 언급하지 않는 일반적 단서를 제시하 여 이야기 다시 말하기를 처치하는 기존 연구들과는 달리 이야기 다시 말하기를 촉진하기 위해 이야기 구조 요소에 직접적으로 해당하는 구체적 단서를 발판으로 제시하여 처치를 더욱 구체 화하기로 했다. 그러면 이야기 구조기반 이야기 다시 말하기 조건과 일반적 단서를 제시하는 다 시 말하기 조건 간에 차이가 있을 것인지 그 상대적 효과도 비교하기로 했다. 이러한 처치 상의 차이점이 이 연구의 또 다른 개선점이기도 하다.

또한 이 연구에서는 석·박사학위 선행연구들과 연구방법 상에서 몇 가지 달리했다. 먼저 연구 대상 면에서 보면, 기존의 초기 연구들에서는 취학전 아동들을 대상으로 하는 연구는 외국에서 
는 비교적 많이 이루지고 있으나(Best, 1993; Cleven, 2005; Isbell, et al., 2004; Morrow, 1985, 1986; Spencer, 2009; Tucker, 2001), 국내에서는 일부 행해졌을 뿐(김경희, 2004; 이수영, 2000; 이현지, 2005; 하양승, 1995) 아주 미흡한 실정으로 여겨진다. 그리고 이야기 지도의 수업 적용은 초등학교 고학년에서 주로 검증되어 왔던 것이 1 학년에서도 효과적인 것으로 밝혀졌다 (Baumann \& Bergeron, 1993). 이 연구에서는 취학전 아동을 대상으로 그 효과를 검증함으로써 이야기 지도 수업의 적용 범위의 확대 가능성을 확인하고자 했다. 이야기 다시 말하기 연구의 실험 참가 아동들의 연령은 3세(예컨대, Isbell, et al., 2004), 4세(예컨대, 이현지, 2005; Cleven, 2005), 5세(예컨대, 이수영, 2000; 하양승, 1995; 홍여찬, 2003; Spencer, 2009) 등 대체로 3-5세에 해당했다. 이 연구에서는 취학전 만 5세 아동들을 실험 참가자로 하기로 했다.

그리고 효과 측정 면에서는 단지 이야기 다시 말하기 조건을 훈련하기 전(사전검사)과 훈련 후(사후검사)를 비교하는 것이 아니라, $\operatorname{Sisco}(1992), \operatorname{Tucker}(2001)$ 의 박사논문에서의 분석방법을 참고하여 훈련 후와 훈련 전의 차이점수를 분석하기로 했다. 왜냐하면 이 연구의 목적은 이야기 다시 말하기의 산출에 미치는 개선효과를 검증하는 것이기 때문이다. 따라서 이야기 다시 말하 기의 산출 검증에서는 전체산출에 미치는 개선효과 검증은 물론 이야기의 각 구조 요소의 산출 에 미치는 개선효과에 차이가 있을지 이야기 다시 말하기 조건들 간의 개선효과를 비교하기로 했다. 또한 대부분의 선행연구들에서 검증하지 않은, 배경·문제·구성·해결·순서의 이야기 구조 요소 간의 산출에 미치는 상대적 효과도 비교하기로 했다.

\section{2. 연구 목적과 연구 문제}

이 연구의 목적은 취학전 만 5세 아동들을 실험 참가자로 하여 이야기 다시 말하기, 이야기 구조기반 이야기 다시 말하기 그리고 통제의 3개 이야기 다시 말하기 조건 간에 유아가 들은 이야기를 다시 말하기 할 적에 처치 전과 처치 후의 그 산출의 변화는 차이가 있는지를 검증하 는 것이다. 이 연구에서 검증하고자 하는 구체적인 연구 문제는 다음과 같다.

첫째, 이야기 다시 말하기, 이야기 구조기반 이야기 다시 말하기 그리고 통제의 3 개 조건 간에 이야기 다시 말하기의 산출의 개선은 차이가 있는가?

둘째, 이야기 다시 말하기의 구조 요소별 산출의 개선은 이야기 다시 말하기 조건에 관계없이 차이가 있는가? 


\section{II. 이론적 배경}

\section{1. 이야기 다시 말하기의 개념과 성격}

이야기 다시 말하기란 성인이 읽어주는(즉, 아동이 들은) 이야기에 대해 아동이 다른 사람에 게 그 내용을 이야기 해주는 활동을 의미한다(Morrow(1996). 이야기 다시 말하기는 듣기 후 활 동으로서 이야기를 재구성하는 기회를 아동에게 제공한다(Cruze de Quiros, et al., 2012). 다시 말하기는 말 또는 글로 나타낼 수 있다. 어느 경우이든 아동은 원래의 교재(글)의 의미를 재구성 하는데 적극적으로 관여하게 된다. 이야기 다시 말하기는 단순히 암기하는 것이 아니라 오히려 이야기하기의 한 형태이다. 즉 자신의 말로 이야기를 말하는 것이다. 그러므로 들은 이야기에 대한 능동적 구성 과정으로서의 아동의 이해를 반영한다. 따라서 성인이 아동에게 이야기를 들 려주는 동화 구연 또는 아동이 글 없는 이야기책을 보고 나름대로 의미를 구성하여 읽으며 말하 는 이야기하기와는 구별된다. 이 연구에서는 훈련자가 읽어주는 이야기를 아동이 듣고 서 그 이 야기를 한 번도 들어본 적이 없는 친구에게 다시 말하게 했다.

이야기 다시 말하기는 두 가지 구성요소로 이루어진다. 즉, 한 요소는 이야기에서 회상된 요소 이며, 다른 한 요소는 말하는 이가 회상했던 것으로부터 새로운 이야기체로 말하는 방식이다. 말하는 이가 새로운 이야기체를 창조할 적에, 그 이야기의 요점은 물론 이야기의 부분들을 의미 연결된 것으로 조직함에 있어 어려움이 나타난다.

이야기 다시 말하기는 듣기와 읽기 중의 두 경우 모두 이야기 이해를 발달시키는 목적에 사용 되어 온 하나의 방략이다. Huston과 Shapiro(1991)의 연구에 의하면, 아동이 이야기 다시 말하기 를 함으로써 문어를 습득하는데 기초가 되는 구어기술을 발달시킬 수 있다고 했다. 문어를 습득 하기 전에 구어기술을 발전시키는 것이 필요하며 이는 언어 학습의 통합적인 부분이며, 예컨대 문어의 기술을 성공적으로 사용할 수 있게 된다.

이야기 다시 말하기는 중요한 학업 기술이다. 이 이야기 다시 말하기 기술은 정보를 해석하고 재구성하는 학습이 읽기 과정의 중요한 부분이기 때문에 읽기를 향상시킨다(Geva \& Olson, 1983). 책을 읽은 후 또는 들은 후에 이야기 다시 말하기는 그 이야기에 대한 아동의 이해와 회상 의 향상을 보인다(Gambrell, Koskinen, \& Kapinus, 1991; Morrow, 1985). 이야기 다시 말하기는 다양한 읽고 쓰는 능력 기능의 발달을 촉진시킬 수 있는 수업 기법으로 제안되어 왔다. 이야기 다시 말하기는 이야기 재구성에서 아동으로 하여금 적극적 역할을 맡게 할 수 있다.

따라서 아동의 경우, 이야기 다시 말하기는 아동이 듣는 교재(글)나 읽는 교재(글)를 아동 자 신의 말로 옮기도록 하는 방법으로서 강력한 학습도구(Brown \& Cambourne, 1987)이다. 한편 교사의 경우, 이야기 다시 말하기는 읽고 이해하는 능력의 성장에 대한 좋은 척도를 제공한다. 
또한 이야기 다시 말하기 과제는 준비하기 쉽고, 융통성 있게 사용할 수 있으며, 아동에게 다양 한 기능을 실습할 수 있게 할 수 있다(Tucker, 2001).

\section{2. 이야기 구조}

취학전 만 5세 아동들의 교육에서는 설명적 교재가 아니라 이야기 교재를 대상으로 하기 때문 에 이 연구에서는 이야기 교재의 구조에 대해서 알아보기로 한다. 전통적으로 이야기 교재는 설 명적 교재와 마찬가지로 그 자체의 내적 구조를 갖고 있다. 예컨대, 간단한 구성 순서에는 주인 공이 직면하는 문제, 그 주인공이 그 문제를 해결하기 위해 행하는 일련의 시도들, 그리고 그 문제의 어떤 해결이 내포되어 있다(Thorndyke, 1977). 그런 사태들 사이의 이야기의 의존성은 독자로 하여금 묵시적인 인과 관계, 기저 목표 및 주인공의 동기에 대한 지식을 기반으로 하여 어떤 구조 요소에 대해 기대를 갖도록 한다. 그래서 연구자들은 이야기 교재에 있는 이런 유형의 지식을 약호화하는 문법을 제안했다.

이야기 문법 연구의 선구자인 Thorndyke(1977)는 모든 이야기의 필수적인 구성요소로서 배 경, 주제, 구성 및 해결의 네 가지를 제안하여 검증했다. Stein과 Glenn(1979)은 이야기를 배경과 하나 이상의 일화 체계의 두 부분으로 나눈 후 이야기 다시 말하기 일화의 계기가 되는 사건, 내적반응, 시도, 결과, 반응의 5개 범주로 나누었다. Mandler와 Johnson(1977)도 이야기 배경, 발단, 반응, 시도, 결과, 결말의 6개 요소로 나누었다. 이와 같이 볼 때, 이야기의 구조는 이야기 의 내용 특성에 따라서 그것을 구성하는 요소가 다를지라도 대부분의 경우는 행위의 동기, 행위 를 위한 계획, 행위의 실행, 행위의 결과를 포함하고 있음을 알 수 있다. 이와 같이 이야기 구조 요소의 분류와 명칭은 다소 달랐으나, 이 연구에서는 가장 기본적인 구조 요소를 배경, 문제, 구 성, 해결, 순서로 나누었다.

그런 일반적인 구조들이 교재기억을 개선하려는 기법으로 이야기 교재의 이해와 회상 중에 사용됨을 입증하려는 연구들이 시도되어 왔다. 가령, 연구자들은 이야기 구조 또는 이야기 문법 에 위배될 때보다는 적합하게 잘 조직될수록 이야기 교재의 이해와 기억이 우수함을 알 수 있다 (문선모, 1997, 2012; Mandler \& Johnson, 1977; Stein \& Glenn, 1979; Thorndyke, 1977).

Mandler와 Johnson(1977)의 연구에서는 이야기 구조 요소의 모든 부분이 똑같이 회상되는 것 은 아니라고 했다. 즉, 초등학생이나 성인 모두 주 배경(major setting), 시발사건, 및 결과를 잘 회상하였지만, 초등학생은 주인공의 내적 반응이나 목표는 잘 회상하지 못했다. 또한 초등학교 4 학년생과 대학생을 대상으로 한 조혜자(1988)의 연구에서도 시발사건과 결과가 잘 회상되는 것 으로 나타났다. 이러한 결과는 시발사건과 결과가 사건에서 인과의 원인과 결말이 되기 때문인 것으로 보인다(조경희.이정모, 1992). 이 연구에서는 이야기 구조 요소들에 대한 취학전 만 5세 
아동들의 회상으로부터의 산출이 초등학생, 대학생, 성인들과 다를 것인지를 검증하고자 했다.

연구들은 이야기 이해에 있어 발달차를 밝혀왔다. 아마 이야기 구조에 대한 감(sense)은 만 4세경에 발달할지라도 성숙함에 따라 이야기 구조에 대한 감은 더욱 정교화 되며, 초등학교 4-6 학년에서 이야기 구조 발달이 현저하게 일어난다(Baumann \& Bergeron, 1993). 이야기 문법은 이야기 다시 말하기를 촉진하는 수단으로 이용될 수 있음이 제안되어 검증되어 왔다(Morrow, 1986).

이런 다양한 이야기 문법 구조 또는 이야기 지도는 이야기 구조의 발달을 촉진시키고 따라서 이야기 이해를 촉진시키기 위해 직접 가르칠 수 있음이 제안되어 왔다. 이야기 구조에 기반을 두는 이야기 지도는 이야기의 요소들의 학습에 도움이 되도록 시각적 표상을 이용하는 방략으 로서 지도를 완성하기 위해선 적극적으로 읽거나 듣기를 하도록 하기 때문에 효과적이다(Davis \& McPherson, 1989). 이야기 구조를 가르치는 것의 효과성을 취학전 아동을 실험 참가자로 한 연구는 많지 않다. 예컨대, Bui(2002)는 학습장애 초등학교 1학년 학생을 대상으로 그림책을 사 용해 검증했고, Hayward와 Schneider(2000)는 언어손상이 있는 취학전 특수아동을 대상으로 검 증했다. 그러나 취학전 정상아동을 대상으로 한 연구는 별로 이루어지지 않았다. 특히 이야기 구조를 지도화하여 취학전 아동의 이야기 다시 말하기에 적용한 연구는 찾기 힘들었다. 따라서 이 연구에서는 취학전 만 5 세 정상아동의 경우에도 이야기 구조를 지도화하여 가르치는 기법을 이야기 다시 말하기에 결합하면 이야기 다시 말하기가 개선 될 수 있을 것인지를 검증하고자 했다.

\section{3. 선행연구의 개관}

이야기 다시 말하기 연구는 이 분야의 선구자인 Morrow(1985) 이후로 주로 유아와 초등학생 을 대상으로 하여 이루어져 많은 주목을 받아왔다. 그 이유는 아마 이야기 다시 말하기는 다양한 읽고 쓰는 기능의 발달을 촉진시킬 수 있는 수업 기법으로 제안되었기(Morrow, 1986) 때문일 것이다.

선행연구들을 검색한 결과, 국외 연구들은 학습장애 학생(Sisco, 1992; Kuldanek, 1998), 읽기장 애 학생(Koskinen, Gambrell, \& Kapinus, 1988; Westerveld, 2010), 주의력결함 과잉행동장애 (John, 2001)의 초등학교 특수학생 등을 주로 대상으로 하였으며, 일반학생(Johnson, 1988; John, 2001) 대상도 일부 이루어졌다. 취학전 아동의 경우는 주로 일반아동을 대상으로 했다(Best, 1993; Cleven, 2005; Tucker, 2001; Isbell, et al., 2004; Morrow, 1985, 1986; Spencer, 2009). 한편, 비교적 최근 국내연구를 살펴보면, 초등학생일 경우, 읽기장애 학생(정현조, 2012), 주의력결함 과잉행동장애 학생(반지정, 2012), 일반학생(반지정, 2012; 이강현, 2001)을 대상으로 이루어졌다. 
취학전 아동의 경우는 발달지체 아동(홍여찬, 2003), 일반 아동(이현지, 2005; 이수영, 2000; 하양 승, 1995)을 대상으로 이루어졌다. 이로 미루어 보면 이야기 다시 말하기 국외연구는 주로 초등 학교 특수학생을 대상으로 비교적 활발히 이루진 반면, 유아 대상 연구는 상대적으로 적음을 알 수 있었다. 반면에 국내연구는 일반 또는 특수학생의 뚜렷한 편중 경향 없이 비교적 적게 이루어 졌음을 알 수 있었다. 특히 한 편(반지정, 2012)만 제외하고 모두 석사논문들이었다. 이 연구에서 는 이야기 다시 말하기 처치조건을 기존 연구들과는 달리하여 취학전 만 5세 일반 아동을 실험 참가자로 하여 그 효과를 검증 하고자 했다.

이야기 다시 말하기의 처치는 앞의 분류에서 밝혔듯이 크게 단순지시, 단서제시, 이야기 문법 (구조)으로 접근하였기에 이를 중심으로 주요 선행연구들을 살펴보기로 한다. 이야기 다시 말하 기의 선구적 연구로 Morrow(1985)는 유치원 일반아동을 실험 참가자로 하여 그림 이야기책을 사용하여 단순지시를 사용한 결과, 이야기 다시 말하기 산출의 경우 전체산출은 실험집단이 통 제집단에 비해 유의한 개선효과를 보였다. 그리고 구조 요소별 개선효과는 주제와 해결 구조 요 소에서는 유의하게 나타났으나, 배경과 구성 구조 요소에서는 유의한 개선효과가 없었다. $\mathrm{John}(2001)$ 역시 초등학교 주의력 결함 과잉행동장애 아동과 일반아동을 대상으로 단순지시로 이야기 다시 말하기를 처치했으나 이야기 구조 요소 간 차이를 검증하여 그 상대적 효과를 검증 하진 않았다.

단순지시로 이야기 다시 말하기를 처치한 국내연구를 살펴보면, 만 5세 유아를 대상으로 한 하양승(1995)의 연구에서는 단순지시로 처치한 결과, 이야기 다시 말하기의 산출 전체와 배경, 문제, 줄거리(구성), 해결, 계열성(순서)의 구조 요소별 산출에 촉진효과를 밝혔다. 만 4,5 세 유아 대상으로 한 이수영(2000)의 연구에서는 실험집단이 통제집단보다 이야기 구성요소의 전체 산 출이 더 높았다. 이 연구 역시 이야기 구성요소별 산출을 분석하지는 않았다. 만 4 세 유아를 대 상으로 한 이현지(2005)의 연구는 사전, 사후 검사를 실시한 결과, 이야기 다시 말하기 전체산출 의 개선효과가 없었다. 등장인물, 배경, 시도된 사건(시도), 문제, 해결 및 결말로 구분한 이야기 구조 요소별 산출의 개선효과도 나타나지 않았다. 최근에 수행한 반지정(2012)의 박사논문에서 는 초등학교 1-3학년의 주의력결함 과잉행동장애 아동들은 일반아동들에 비해 이야기 다시 말 하기 산출로서 이야기 문법 표현 능력에서 장애 아동들이 현저히 낮음을 밝혔다. 그러나 이야기 문법 구조 요소별로는 계기사건, 결과, 시도, 배경, 내적 반응의 구조 요소 간 차이를 검증을 하 지 않아 그 상대적 효과를 검증하지는 않았다. 초등학생을 대상으로 한 이강현(2001)의 연구에서 는 연령에 따른 이야기 구조를 분석했으나, 역시 환경(배경), 내적 반응, 시도, 결과, 시발사건, 시도 및 반응 간의 산출의 상대적 효과를 검증하지는 않았다. 단순지시로 처치한 이상의 연구들 을 보면, Morrow(1985), 이현지(2005)의 연구를 제외하고 다른 연구들은 실험집단과 통제집단을 비교하였을 뿐 사전검사, 사후검사의 실험설계를 하지 않아 사전, 사후의 변화로 그 개선효과를 
검증하지 않았다.

한편, 단서제시로 이야기 다시 말하기를 처치한 연구로서 Greathouse(1991)의 박사논문에서 는 이야기 다시 말하기 기회를 가진 아동은 그렇지 않은 아동에 비해 그 아동의 이야기 다시 말하기에 이야기 구조 요소들이 더 많이 반영되어 개선효과가 나타났다. 또 다른 단서제시 접근 으로 Tucker(2001)의 박사논문에서는 유치원 아동에게 이야기 다시 말하기를 안내하는 실습을 한 실험조건의 아동들이 통제조건보다 이야기 다시 말하기 전체산출에서 더 큰 개선효과를 보 였다. 구조 요소별 산출의 개선효과는 배경, 시발사건, 기타 사건들에서 유의하게 나타났으나, 등장인물과 해결 구조 요소에서는 개선효과가 없었다.

한편, 이야기 문법(구조) 접근의 최초 연구로서 $\operatorname{Morrow}(1986)$ 의 연구에서는 유치원 아동을 대상으로 그림 이야기책을 사용한 결과, 이야기 다시 말하기의 구조 요소 산출에서 실험집단은 통제집단보다 배경과 구성 요소에서 유의하게 더 잘 수행했다. 그리고 실험집단은 사전검사에 비해 사후검사에서 배경, 문제, 구성, 해결, 순서의 모든 구조 요소에서 더 큰 개선효과를 보였다. 그러나 구조 요소들 간에 산출에 미치는 상대적 효과를 비교·검증하지는 않았다. Kuldanek(1998)은 초등학교 1-2학년 학습장애 학생 10명을 대상으로 사전, 사후검사 결과, 이 야기 다시 말하기 산출의 개선에 미치는 긍정적 효과를 입증했다. $\operatorname{Sisco}(1992)$ 는 5-7세 학습장 애 학생을 대상으로 사전, 사후검사 결과, 이야기 다시 말하기 전체산출의 개선효과를 보였고, 이야기 구조 요소별 산출의 개선효과는 배경, 구성, 해결 요소에서는 긍정적이었으나, 주제 요소 에서는 유의한 개선효과가 나타나지 않았다. Cruz de Quiros 외(2012)는 이중언어 학습자 초등 학교 1-2학년의 경우 배경, 등장인물, 구성, 문제, 해결의 5 개 이야기 요소 모두의 산출을 실험 집단이 비교집단보다 잘 수행했음을 밝혔다. 그러나 개선효과를 검증하진 않았다.

앞에서 언급했듯이 단순지시 접근은 지시의 모호성이 그리고 단서제시 접근은 이야기 구조와 의 관련성의 인지 곤란이 문제점으로 보여 이 연구에서는 이야기 문법(구조) 접근을 채택했다. 그런데 Morrow(1986)의 연구에서는 구조 안내와 실습, Kuldanek (1998)의 연구에서는 이야기 문법 요소의 모델링과 실습, $\operatorname{Sisco}(1992)$ 의 연구에서는 이야기 구조의 직접수업을 시도했으나, 이들은 모두 초등학교 학생들을 실험 참가자로 하였으며, 이야기 지도 수업 기법을 적용하지는 않았다. Baumann과 Bergeron(1993)에 의하면, 많은 연구자들은 다양한 이야기 문법 구조와 이 야기 지도 의 도식 표상(graphic representation)은 이야기 이해를 촉진시키기 위해 직접 가르칠 수 있다고 제안하여 왔었다. 이야기 문법 또는 이야기 지도 수업은 학생들의 이야기 이해를 개선 시킬 수 있음이 입증되었다(Baumann \& Bergeron, 1993; Bui, 2002).

지금까지 이야기 지도 수업은 대부분 초등학교 고학년을 대상으로 이야기 이해에 미치는 효 과를 검증하는 데 적용되어 왔다. 이 기법을 Baumann과 Bergeron(1993)은 초등학교 1학년에 적 용하여 그 적용 범위를 확대했다. 이 이야기 지도 수업을 취학전 아동을 대상으로 이야기 다시 
말하기 산출에 적용하여 그 효과를 검증한 연구는 찾기 힘들었다. 따라서 이 연구에서는 초등 학교 1학년에 적용한 Baumann과 Bergeron(1993)의 연구에 기반하여, 취학전 만 5세 아동에게 도 적용 가능한지 시도해보고자 했다. 또한 기존 연구들에서는 이야기 다시 말하기 기법만 따로 적용하여 왔으나, 이 연구에서는 이야기 지도 수업 기법을 이야기 다시 말하기와 함께 결합하여 이야기 다시 말하기의 산출에 미치는 효과를 검증하고자 했다.

\section{III. 연구방법}

\section{1. 실험 참가자}

이 연구의 실험 참가자는 진주시에 소재한 어린이 집들 중에서 무작위 표집한 E어린이집의 취학전 만 5 세 남자 아동 17 명과 여자 아동 13 명, 전체 아동 30 명을 모집단으로 했다. 이들 중 인지장애 2 급 아동 1 명과 다문화가정의 언어표현이 떨어지는 아동 2 명을 제외한 27 명을 대상으 로, 이야기 다시 말하기 집단(남 3, 여 6), 구조기반 이야기 다시 말하기 집단(남 7, 여 2), 통제집 단(남 6, 여 3)에 각 9명씩 무작위 배정했다.

\section{2. 실험도구}

1) 이야기 자료

이 연구에 사용된 이야기책들은 Morrow(1986), Sisco(1992), Tucker(2001) 등의 선행연구들을 참고하여 다음의 선정 준거에 의거해 선정되었다. 구체적인 선정 준거는 다음과 같다. 첫째, 등 장인물들, 시간과 장소 등 분명한 배경이 있는 이야기, 둘째, 주인공 또는 등장인물이 직면하는 문제 또는 어려움이 있는 이야기, 셋째, 주요 등장인물들의 문제 해결 또는 목표의 달성으로 유 도하는 구성 에피소드들이 있는 이야기, 넷째, 해결의 이야기 구조가 잘 반영되어 있는 이야기, 다섯째, 어렵지 않고 낮설지 않으며, 친숙한 개념들로 서술된 이야기, 여섯째, 아동이 들은 적이 없는 이야기.

이야기책의 최종 선정은 연구자, 어린이집 전문교사 2 명의 협의와 전문교수 1 명의 자문을 받 아 이루어졌다. 그리고 선정된 이야기책의 길이가 지나치게 긴 경우는 적절하게 조절했다. 용도 별 선정된 이야기책은 사전검사용 1 권, 예시용 1 권, 훈련용 3 권, 사후검사용 1 권 전체 6 권이었다. 
2) 이야기 다시 말하기 검사 자료

이 검사는 아동으로 하여금 실험자가 들려주는 이야기를 들은 후, 훈련자를 그 이야기를 한 번도 들은 적이 없는 친구라고 생각하여 자유롭게 이야기 다시 말하기를 하도록 하게 하는 검사 이다. 이 검사는 아동이 산출한 이야기 다시 말하기 반응지(protocol)에서 이야기 구조 요소를 어떻게 포함했는지를 분석하기 위해 사용된다.

\section{3. 실험설계}

이 연구에는 혼합, 피험자간, 피험자내 설계(a mixed, between subjects, within subjects, design)를 적용했다. 피험자간 변인은 이야기 다시 말하기 조건(이야기 다시 말하기·구조기반 이야기 다시 말하기 조건·통제조건)이고, 피험자내 변인은 검사시기(사전·사후) 이었다. 따라 서 독립변인은 이야기 다시 말하기 조건과 검사시기이며, 준거변인은 이야기 다시 말하기 전체 산출 및 개개 구조요소 산출에서 사후검사와 사전검사의 차이점수이다.

\section{4. 실험절차}

1) 실험 보조자 사전교육

연구자 1 명과 보조자 2 명(유아교육을 전공한 어린이집 전문교사)이 한 집단씩 실험을 수행했 다. 실험을 원활하게 운영하기 위해 실험의 모든 과정에 대해 연구자가 모델링을 하고, 사전 모 의훈련을 하여 실험수행의 문제점을 미리 파악하고 보완했다.

\section{2) 사전검사}

3개 집단에게 각각 사전검사용 이야기책 “금강초롱”을 읽어준(들은) 후, 아래의 지시문대로 아동 개개인에게 이야기 다시 말하기를 하게 하여 개별적으로 녹음했다. 실시시간은 개개 아동 마다 평균적으로 25 30분 정도였다.

오늘 선생님이 너에게 이야기를 읽어주고, 너는 선생님이 읽어주는 이야기를 들어요. 주의 깊게 들 은 다음, 그 이야기를 이전에 한 번도 들어본 적이 없다고 생각하는 너의 친구에게 이야기 하도록 시킬 거예요. 네가 기억할 수 있는 한 이야기를 많이 하기 바랍니다. 
3) 이야기 다시 말하기 집단 (조건 1)의 실험절차

아래의 순서대로 이야기 다시 말하기를 4 일(월 금)에 걸쳐 이야기책 4 권을 사용하여 가르쳤다.

(1) 이야기 다시 말하기를 사전검사의 지시문대로 지시한다.

(2) 예시용 이야기책(바람과 해님)를 읽어준다/아동은 듣는다.

(3) 발판으로 기능하도록 아래와 같이 이야기 구조 요소에 해당하지 않는 비교적 짧은 물음을 일반적인 단서로 제시하여 이야기 다시 말하기를 한다.

자, 자, 선생님이 그 이야기를 한 번도 들은 적이 없는 그 친구라고 생각해요. 그럼 그 이야기 나 에게 말해 봐요.

(오래 멈추거나, 반응이 없으면 다음 단서를 제시한다.)

종종 그 이야기에 일어났던 것들을 기억하여 그것들을 이야기 다시 말하기란 어려울 수 있어요. 그래서 오늘 선생님은 약간의 힌트를 줄려고 해요.

이야기 다시 말하기를 네가 시작할지에 관해 생각해 봐요 ... 그리고 이제 나에게 말해 봐요. (오래 멈추거나, 반응이 없으면 다음 단서를 제시한다.)

이야기 다시 말하기를 시작하기가 어렵다는 것을 선생님도 알아 . . . 그 이야기의 시작부분으로 돌아가서 생각해 봐요 그리고 그 시작부분에 누가 나왔는지, 처음에 일어났던 일들 중 하나가 무 엇인지 생각해 봐요.

좋아요 ... 그밖에 다른 것들을 생각할 수 있겠어요? 그밖에 다른 무엇이 일어났어요? 앞에서 말한 일어난 일/사건)에 관해 또 다른 무엇을 나에게 말할 수 있겠어요?

그리고 그래서 어떻게 되었어요? 그밖에 또 무엇이 일어났어요? 나에게 많은 것을 말해 줄 수 있도록 생각하도록 해봐요 . . 그밖에 또 다른 무엇이 일어났어요? 마지막으로, 이야기는 어떻게 끝났어요?

\section{4) 구조기반 이야기 다시 말하기 집단 (조건 2)의 절차}

4 일(월 금)에 걸쳐 이야기책 4 권을 사용하여 가르쳤다. 이 조건과 앞의 이야기 다시 말하기 조건과의 차이는, 먼저 이야기 구조 요소에 대한 지도를 작성하여 이해를 돕기 위해 그것을 시각 적으로 제시하여 가르친 다음에 이야기 다시 말하기를 실시했다. 그런데 앞의 이야기 다시 말하 기 조건에서는 이야기 구조 요소에 해당하지 않는 일반적인 단서를 발판으로 제공하였으나, 이 조건에서는 발판으로 기능하도록 구조 요소에 해당하는 물음을 구체적인 단서로 제공했다.

단계 1: 이야기 구조 요소를 이야기 지도작성 지침에 의거해 가르친다. 이야기 지도작성의 예 는 다음 [그림 1]과 같다. 
단계 2. 이야기 다시 말하기 절차에 따라 이야기 다시 말하기를 가르친다.

(1) 이야기 다시 말하기를 사전검사의 지시문대로 지시한다.

(2) 예시용 이야기책(바람과 해님)을 읽어준다/ 아동은 주의 깊게 듣는다.

(3) 자유롭게 이야기 다시 말하기를 하도록 한다.

자, 선생님(훈련자)을 그 이야기를 한 번도 들은 적이 없는 그 친구라고 생각하고. 그럼 그 이야기 를 나에게 말해보세요.

(4) 안내하는 발판으로 구체적인 단서를 제공하여 이야기 다시 말하기를 하게 한다.

자, 자, 선생님이 그 이야기를 한 번도 들은 적이 없는 그 친구라고 생각하고. 그럼 그 이야기를 나에게 말해보세요.

(오래 멈추거나, 반응이 없으면 다음 단서를 제시한다.)

\section{이야기 지도 작성 공부 자료}

예시용 이야기 "바람과 해님"

\begin{tabular}{|c|c|}
\hline 배경 & \\
\hline$\rightarrow$ & $\begin{array}{l}\text { 누구? (등장인물) } \\
\text { "바람과 해님" 이야기에서 가장 중요한 사람들은 누구 였나요? } \\
\text { 정답 : }\end{array}$ \\
\hline$\rightarrow$ & $\begin{array}{l}\text { 어디에? (장소) } \\
\text { 이 이야기는 어디(장소)에서 일어났나요? } \\
\quad \text { 정답 : }\end{array}$ \\
\hline$\rightarrow$ & $\begin{array}{l}\text { 언제? (시간) } \\
\text { 이 이야기는 언제(시간) 일어났나요? } \\
\quad \text { 정답 : }\end{array}$ \\
\hline
\end{tabular}

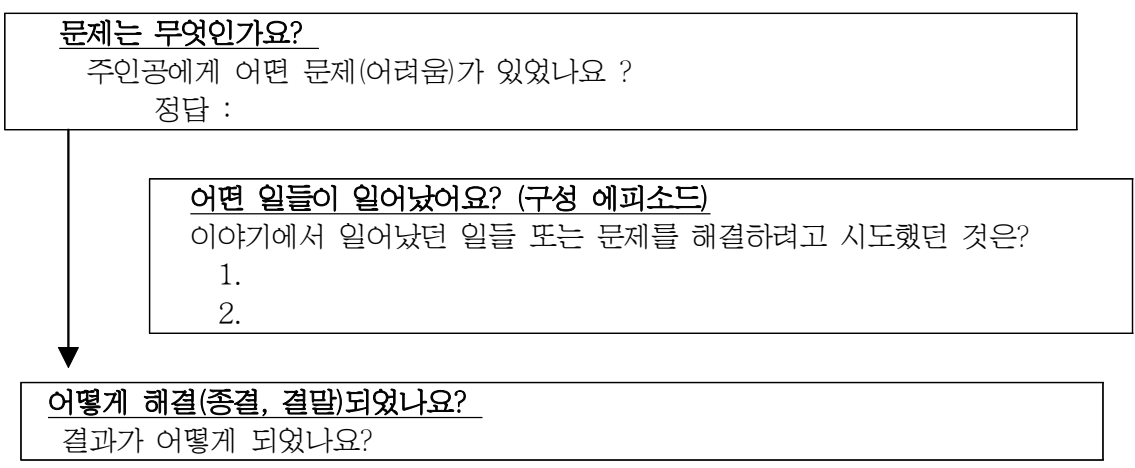


종종 그 이야기에 일어났던 것들을 기억하여 그것들을 이야기 다시 말하기란 어려울 수 있어요. 그래서 오늘 선생님은 약간의 힌트를 줄려고 해요.

어떻게 이야기 다시 말하기를 네가 시작할지에 관해 생각해 봐요 . . . 그리고 이제 나에게 말해 보세요.

(오래 멈추거나, 반응이 없으면 다음 단서를 제시한다.)

이야기 다시 말하기를 시작하기가 어렵다는 것을 선생님도 알아요 . . 그 이야기의 시작부분으 로 돌아가서 생각해 봐요 그리고 그 시작부분에 누가 나왔는지, 처음에 일어났던 일들 중 하나가 무엇인지 생각해보세요.

선생님이 힌트를 하나 주겠어요. 누구에 대한 이야기였나요? 이 이야기는 어떻게 시작되었나 요? 이야기의 문제가 무엇이었나요? 그 주인공(등장인물)이 문제를 어떻게 해결하려고 했나요? 그 주인공은 처음에 무엇을 했나요? 그다음에, 무엇을 했나요? . . . 그리고 그다음에는 무엇을 했나요? 좋아요. (방금 말한 것 말고) 그밖에 다른 것을 말할 수 있겠어요 . . ? 어디에서 일어난 일인지 그 장소를 말해 봐요. 그밖에 다른 무엇은 . . . ? 그리고 그다음에는 . . . ? 그 이야기에 대해 친구에게 말해줄 수 있는 또 다른 무엇이 있나요? 그 이야기는 어떻게 끝났어요?

5) 통제집단의 실시 절차

(1) 이야기를 소개한다.

"선생님이 너에게 이야기책을 하나 읽어주려고 해요. 이야기책의 제목은 이예요. 그 이 야기는 에 관한 것이예요.”

(2) 이야기책을 읽어준다. / 아동은 주의 깊게 듣는다.

이야기 의미를 적절히 전하기 위해 억양과 표현을 사용한다. 만일 아동이 질문을 하거나, 의견을 말하면, 그 것을 받아들여 질문에 간단히 답하나, 자세히 설명하진 않는다.

\section{6) 사후검사}

3 개 집단에게 이이야기 다시 말하기 조건의 효과를 측정하기 위해 이야기책 “금구슬"을 읽어 준 후, 사전검사와 동일한 방법으로 이야기 다시 말하기를 아동마다 개별적으로 녹음했다. 이야 기 다시 말하기의 지시문은 사전검사와 동일했다. 실시시간은 개개 아동마다 평균적으로 25 30 분 정도였다. 


\section{5. 자료처리}

이야기 다시 말하기 검사의 채점은 먼저 아동이 이야기 다시 말하기를 한 녹음을 그대로 전사 하여 이것을 채점을 위한 반응지로 사용했다. Morrow(1986)의 채점기준을 참조하여 작성한 다 음 <표 1 의 채점 기준표에 의거하여 구조 요소별로 채점했다. 각 구조 요소별 비교를 위해 만 점(10점)을 동일하게 조정했다. 채점자간 신뢰도를 알아보기 위해 이야기 다시 말하기 사후검사 중에서 무작위 표집한 아동 5명의 반응지에 대한 채점자간 일치율은 $90.0 \%$ 였다.

자료 분석은 먼저 이야기 다시 말하기 검사의 검사시기별로 실험조건별 평균과 표준편차를 계산했다. 실험조건의 개선효과를 검증하기 위해 사후검사 점수에서 사전검사 점수를 뺀 점수를 개선점수로 삼았다. 이야기 다시 말하기 전체의 개선효과 검증을 위해선 개선점수에 대해

<표 1> 각 이야기 구조의 각 요소별 구체적인 채점기준표

\begin{tabular}{|c|c|c|c|c|}
\hline $\begin{array}{l}\text { 번 } \\
\text { 호 }\end{array}$ & 이야기 구조 요소 & $\begin{array}{l}\text { 원 } \\
\text { 점수 }\end{array}$ & $\begin{array}{l}\text { 원점 } \\
\text { 수계 }\end{array}$ & $\begin{array}{l}\text { 조정 } \\
\text { 점수 }\end{array}$ \\
\hline \multirow{5}{*}{1} & 배경 (최대 원점수 4점) & & & \\
\hline & A. 이야기는 발단진술문으로 시작한다. & & & \\
\hline & $\begin{array}{l}\text { B. 한 사람 이상의 중심인물 등이 나타나고, 이야기 전반을 통해 주요 } \\
\text { 역할을 맡는다. (주인공) }\end{array}$ & & & \\
\hline & C. 이야기의 시간이 언급된다. (시간) & & & \\
\hline & D. 이야기의 장소가 언급된다. (장소) & & & \\
\hline \multirow{3}{*}{2} & 문제(주제) (최대 원점수 2점) & & & \\
\hline & A. 주인공이 반응하도록 하는 원인이 되는 시작 시발사건이 일어난다. & & & \\
\hline & $\begin{array}{l}\text { B. 주인공으로 하여금 문제를 해결하도록 또는 이 야기의 목표를 달성하 } \\
\text { 도록 유도하는 하나의 사건 또는 일련의 사건들이 일어난다. }\end{array}$ & & & \\
\hline \multirow{3}{*}{3} & 구성 에피소드들 (최대 원점수 2점) & & & \\
\hline & A. 주인공과 관련되는 하나의 사건 또는 일련의 사건들이 언급된다. & & & \\
\hline & $\begin{array}{l}\text { B. 주인공으로 하여금 문제를 해결하도록 또는 이야기의 목표를 달성하 } \\
\text { 도록 유도하는 하나의 사건 또는 일련의 사건들이 일어난다. }\end{array}$ & & & \\
\hline \multirow{4}{*}{4} & 해결(종결) (최대 원점수 3점) & & & \\
\hline & A. 주인공이 문제를 해결하거나 목표를 달성한다. & & & \\
\hline & B. 이야기는 끝마침 진술문으로 종결된다. & & & \\
\hline & C. 결말은 장기적인 결과들로 언급된다. & & & \\
\hline \multirow[b]{2}{*}{5} & 계열(순서) (최대 원점수 4점) & & & \\
\hline & $\begin{array}{l}\text { A. 이야기 구조의 } 4 \text { 개 요소들이 순서대로 제시 된다(배경, 문제, 구성 } \\
\text { 에피소드, 해결). 순서가 맞을 경우 각 요소마다 } 1 \text { 점을 준다. }\end{array}$ & & & \\
\hline 6 & 체 & & & \\
\hline
\end{tabular}


실험조건(이야기 다시 말하기 · 구조기반 이야기 다시 말하기 · 통제)에 따른 일원배치 변량분석 을 실시했다. 그리고 구조 요소별 이야기 다시 말하기의 개선효과의 검증을 위해선 동일한 방식 으로 각 구조 요소별 개선점수를 계산하여 실험조건과 구조 요소(배경·문제·구성·해결·순서)에 따른 $3 \times(5)$ 반복측정 변량분석을 실시했다.

\section{III. 결 과}

\section{1. 이야기 다시 말하기 전체 산출의 변화}

이야기 다시 말하기 전체 산출의 사전 및 사후검사 점수와 개선점수에 대한 이야기 다시 말하 기 조건별 평균과 표준편차는 <표 $2>$ 와 같다. <표 $2>$ 에서 이야기 다시 말하기 산출 전체의

<표 2> 집단별 이야기 다시 말하기 전체산출점수 및 개선점수의 평균(표준편차)

\begin{tabular}{cccc}
\hline 구 분 & 이야기 다시 말하기 & 구조기반 이야기 다시 말하기 & 통제 \\
\hline 사전검사 & $21.27(13.9)$ & $20.96(15.53)$ & $23.51(20.15)$ \\
사후검사 & $28.26(11.24)$ & $37.58(9.09)$ & $15.46(14.95)$ \\
\hline 개 선 & $7.54(19.67)$ & $16.62(19.57)$ & $-8.06(14.94)$ \\
\hline
\end{tabular}

개선점수는 구조기반 이야기 다시 말하기 조건 $(M=16.62)$ 이 가장 높았고, 다음은 이야기 다시 말하기 조건 $(M=7.54)$, 통제조건 $(M=-8.06)$ 의 순으로 나타났다. 이러한 결과는 변량분석 결과 통계적으로 유의한 차이였다 $[F(2,24)=4.236, M S e=331.016, p<.05)$. 3개 조건 간 평균차를 Tukey의 사후 개별비교법으로 검증한 결과, 그 개선효과는 구조기반 이야기 다시 말하기 조건 과 이야기 다시 말하기 조건 간에는 차이가 없었으나, 이 두 조건은 통제조건보다는 유의하게 컸다(구조기반 이야기 다시 말하기 조건 $=$ 이야기 다시 말하기 조건 >통제조건). 이는 취학전 아동에게 이야기 다시 말하기를 이야기 지도작성의 구조기반으로 가르치거나 일반적 단서 중심 으로 가르치는 것이 전혀 가르치지 않는 것보다 이야기 다시 말하기 전체 산출의 개선에 효과적 임을 의미한다.

\section{2. 이야기 다시 말하기 구조 요소별 변화}

이야기 다시 말하기 구조 요소별 산출의 사전 및 사후검사 점수와 개선점수에 대한 이야기 
다시 말하기 조건별 평균과 표준편차는 다음 <표 3>과 같다. 첫째, <표 3>에서 구조 요소별 산출 <표 3> 집단별 이야기 다시 말하기 구조 요소별 산출점수 및 개선점수의 평균(표준편차)

\begin{tabular}{|c|c|c|c|c|}
\hline & 구 분 & 이야기 다시 말하기 & 구조기반 이야기 다시 말하기 & 통제 \\
\hline \multirow{3}{*}{$\begin{array}{l}\text { 배 } \\
\text { 경 }\end{array}$} & 사전검사 & $2.50(1.25)$ & $3.89(3.77)$ & $3.89(2.53)$ \\
\hline & 사후검사 & $3.89(2.83)$ & $7.78(3.17)$ & $3.61(2.20)$ \\
\hline & 개 선 & 1.39 (3.09) & 3.89 (4.53) & $-0.28(2.32)$ \\
\hline \multirow{3}{*}{$\begin{array}{l}\text { 문 } \\
\text { 제 }\end{array}$} & 사전검사 & $5.00(4.33)$ & $4.44(5.27)$ & $3.89(4.86)$ \\
\hline & 사후검사 & $2.22(3.63)$ & $5.56(4.64)$ & 1.11 (3.33) \\
\hline & 개 선 & $-2.22(6.67)$ & $1.11(8.21)$ & $-2.78(4.41)$ \\
\hline \multirow{3}{*}{$\begin{array}{l}\text { 구 } \\
\text { 성 }\end{array}$} & 사전검사 & $6.11(4.86)$ & $5.00(4.33)$ & $5.00(5.00)$ \\
\hline & 사후검사 & $7.22(4.41)$ & $10.0(0.00)$ & $3.33(4.33)$ \\
\hline & 개 선 & $1.11(7.41)$ & $5.00(4.33)$ & $-1.67(4.33)$ \\
\hline \multirow{3}{*}{$\begin{array}{l}\text { 해 } \\
\text { 결 }\end{array}$} & 사전검사 & $2.93(1.98)$ & $2.93(2.58)$ & 4.07 (4.93) \\
\hline & 사후검사 & $7.38(2.80)$ & $7.02(3.90)$ & $2.96(4.54)$ \\
\hline & 개 선 & $4.44(4.09)$ & $4.09(3.24)$ & $-1.11(3.33)$ \\
\hline \multirow{3}{*}{$\begin{array}{l}\text { 순 } \\
\text { 서 }\end{array}$} & 사전검사 & $4.72(3.63)$ & $4.72(4.04)$ & $5.28(4.23)$ \\
\hline & 사후검사 & $7.50(1.77)$ & $7.22(2.92)$ & $4.72(3.41)$ \\
\hline & 개 선 & $2.78(4.04)$ & $2.50(5.3)$ & $-0.56(1.67)$ \\
\hline
\end{tabular}

의 개선점수는 해결 $(M=2.47)$ 이 가장 높았고, 배경 $(M=1.67)$, 순서 $(M=1.57)$, 구성 $(M=1.48)$, 문 제 $(M=1,29)$ 의 순으로 낮았다. 이러한 결과는 변량분석 결과 통계적으로 유의한 차이였다 $[F(4$, $96)=4.352, M S e=12.858, p<.05)$. 5개 구조 요소 간 평균차를 Tukey의 사후 개별비교법으로 검 증한 결과 해결, 배경, 순서, 구성 요소 간에는 유의한 차이가 없었고, 이들 4 개 구조 요소는 문제 요소보다 유의하게 높았다(해결=배경=순서=구성>문제). 그런데 이러한 구조 요소 간 의 차이는 이야기 다시 말하기 조건 따라 다를지 같을지를 알아본 구조 요소와 이야기 다시 말하기 조건의 상호작용효과는 통계적으로 유의하지 않았다 $[F(4,96)=1.110, M S e=12.858]$. 이는 구조 요소별 산출의 개선효과는 이야기 다시 말하기 조건에 관계없이 동일하게 나타남을 의미한다. 이는 취 학전 아동의 경우 이야기 다시 말하기를 가르치면 이야기의 문제 구조 요소의 산출이 가장 힘들 었음을 보여준다.

둘째, 각 구조 요소 산출의 개선은 조건 간에 차이가 있는지를 알아보기 위해, 변량분석 결과 유의하지는 않았지만 시각적 대비를 위해 조건과 구조 요소 간 상호작용효과를 그림으로 나타내 면 다음 [그림 2]와 같다. 


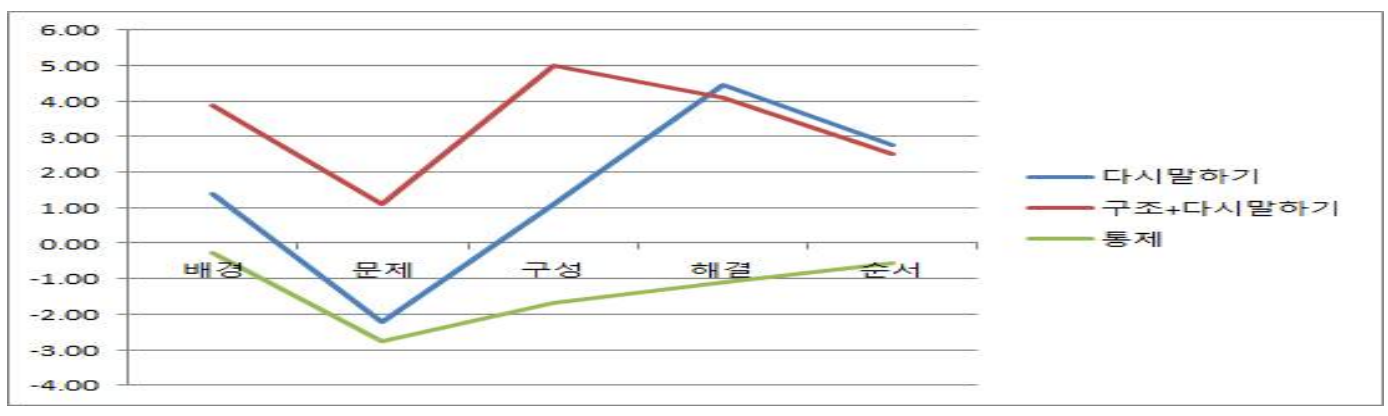

[그림 2] 조건과 구조 요소 간 상호작용효과

[그림 2]에서 각 구조 요소별로 세 조건 간 비교를 위해 각각 일원 변량분석한 결과는 다음 <표 4>와 같다. Tukey의 사후 개별비교 검증법을 적용한 결과, 해결 구조 요소에서만 유의한

<표 4> 이야기 구조 요소별 변량분석표

\begin{tabular}{ccccccc}
\hline 구조요소 & 변산원 & 자승화 & 자유도 & 평균자승화 & $F$ & $p$ \\
\hline \multirow{2}{*}{ 배경개선 } & 집단간 & 79.167 & 2 & 39.583 & 3.353 & .052 \\
& 집단내 & 283.333 & 24 & 11.806 & & \\
\hline \multirow{2}{*}{ 문제개선 } & 집단간 & 79.630 & 2 & 39.815 & .910 & .416 \\
& 집단내 & 1050.000 & 24 & 43.750 & & \\
\hline \multirow{2}{*}{ 구성개선 } & 집단간 & 201.852 & 2 & 100.926 & 3.278 & .055 \\
& 집단내 & 738.889 & 24 & 30.787 & & \\
\hline \multirow{2}{*}{ 해결개선 } & 집단간 & 174.092 & 2 & 87.046 & $6.808^{*}$ & .005 \\
& 집단내 & 306.880 & 24 & 12.787 & & \\
\hline \multirow{2}{*}{ 순서개선 } & 집단간 & 61.574 & 2 & 30.787 & 1.956 & .163 \\
& 집단내 & 377.778 & 24 & 15.741 & & \\
\hline \multirow{2}{*}{$*$} & & & & & \\
\hline
\end{tabular}

$* p<.05$

차이가 있었다 $[F(2,24)=6.808, p<.05]$. 즉, 구조기반 이야기 다시 말하기 조건과 이야기 다시 말하기 조건은 통제조건보다 해결 구조의 개선효과가 더 컸다. 그러나 구조기반 이야기 다시 말 하기 조건과 이야기 다시 말하기 조건 간에는 개선효과의 차이가 없었다. 이는 다시 말하기를 가르치는 것은 전혀 가르치지 않는 것보다 이야기의 구조 중 해결 구조 요소의 개선에 효과적임 을 의미한다. 한편, 조건 간에 통계적으로 유의한 차이는 없었으나, 배경구조의 개선 $(p=.052)$ 과 구성구조의 개선 $(p=.055)$ 은 유의수준에 매우 근접했다. 즉, [그림 2]에서 볼 수 있듯이 구조기반 이야기 다시 말하기 조건은 통제조건보다 배경구조와 구성구조의 개선이 훨씬 커 보이나 통계 적 유의성 수준에는 약간 미치지 못했다. 


\section{V. 논의 및 결론}

첫째, 이야기 지도를 시각적으로 제시하여 이야기 구조에 대해 수업을 행하고 이야기 구조 요소에 대한 구체적 단서를 발판으로 제시하여 이야기 다시 말하기를 훈련하는 이야기 구조기 반 이야기 다시 말하기 조건과 이야기 구조에 대한 지도 없이 단지 이야기 구조 요소에 직접적 으로 해당하지 않는 일반적 단서를 발판으로 제시하는 이야기 다시 말하기 조건은 통제조건에 비해 이야기 다시 말하기 전체산출의 개선에 긍정적 효과를 미쳤다. 그러나 구조기반 이야기 다시 말하기 조건과 이야기 다시 말하기 조건 간에는 차이가 없었다. 그리고 배경, 문제, 구성, 해결의 이야기 구조 요소 각각의 산출에 미치는 개선효과는 해결 구조 요소에서만 나타났다. 한 편, 배경 구조 요소의 개선 $(p=.052)$ 과 구성 구조 요소의 개선 $(p=.055)$ 은 조건 간에 통계적으로 유의한 차이는 없었으나, 유의수준에 매우 근접했다. 따라서 이 연구 결과는 배경과 구성 구조 요소의 산출은 개선 가능함을 강력히 시사한다.

이 연구에서는 이야기 지도 수업을 적용한 구조기반 이야기 다시 말하기를 취학전 아동에게 처음으로 시도·검증하였기에 직접 비교할 수 있는 선행연구들을 찾기는 힘들었다. 비록 이 연구 와 완전 일치하는 접근은 아닐지라도 유치원 일반 아동들에게 단순지시를 처치한 Morrow(1985) 의 연구에서는 전체산출과 문제(주제) 및 해결 구조 요소에서만 개선효과가 입증되어 유사한 결 과를 보였다. 또한 단서제시로 처치한 Greathouse(1991)와 Tucker(2001)의 연구 그리고 초등학 교 학습장애 학생을 대상으로 이야기 문법(구조) 기반 접근을 처치한 Kuldanek(1998)의 연구에 서 입증된 전체 산출의 개선효과는 이 연구와 유사했다. 그러나 Greathouse(1991)와 Kuldanek(1998)의 연구에서는 이 연구처럼 구조 요소 각각에 미치는 개선효과를 분석하지는 않 았다. 한편, 구조 요소 각각에 미치는 개선효과를 분석한 Tucker(1998)의 연구에서는 이 연구와 는 달리 배경, 시발사건, 기타 사건들의 요소에서는 나타났으나, 등장인물과 해결 구조 요소에서 는 보이지 않았다. 그러나 이야기 문법(구조) 접근의 최초 연구로서 유치원 아동을 대상으로 한 Morrow(1986)의 연구에서는 배경, 문제, 구성, 해결, 순서의 모든 구조 요소에서 개선효과가 입 증되었으며 특히 해결 구조 요소에서 개선효과를 보인 점은 이 연구와 일치했다. 그리고 이 연구 결과와 직접 비교 할 수는 없으나 관련연구로서 만4세 유아를 대상으로 단순지시로 접근한 이현 지(2005)의 연구에서는 사전, 사후검사 결과 전체산출과 구조 요소별 산출에 미치는 개선효과는 나타나지 않았다.

지금까지 이야기 지도 수업은 주로 초등학교 고학년이나 일부 1학년에서 검증되었다(예컨대, Baumann \& Bergeron, 1993). 이런 점에 비추어 보면 이 연구 결과는 취학전 아동에게서 비록 일반적 단서 중심의 이야기 다시 말하기 조건과는 통계적으로 유의한 차이가 없으나 통제조건 에 비해 그 효과를 입증함으로써, 이 기법의 수업 적용 가능성을 보다 확대한 것에 이 연구의 
의의가 있다 하겠다.

이 연구에서 이야기 다시 말하기 수업이 이야기 다시 말하기 산출의 개선에 미치는 긍정적 효과가 나타난 것에 대해선 연구방법과 이론적 측면 두 가지 면에서 설명할 수 있겠다. 먼저 무 엇보다도 이야기 다시 말하기 처치의 차이점에서 찾을 수 있을 것 같다. 선행연구들에서는 전통 적으로 다시 말하기를 단순지시나 단서제시로 처치하거나 또는 이야기 문법의 구조에 대해 막 연한 일반적인 단서로 안내를 했다. 그런데 이 연구에서는 이야기 문법 구조에 대한 아동의 이해 를 돕기 위해 이야기 구조 요소에 대한 이야기 지도를 시각적으로 제시하고 네 번에 걸쳐 구체 적으로 가르쳤다. 이 수업 과정에서 개개 아동들의 이해를 개별적으로 확인·지도하였기에 아마 이야기 구조에 대한 아동들의 인식이 높아졌을 것이다.

다른 한편 이론적으로 살펴보면, 이야기 지도 수업에 처치한 이야기 지도는 일종의 시각 교재 조직자(visual graphic organizer)로 볼 수 있다(문선모·전유진, 1996). 이야기 지도와 같은 시각 적 부가 보조수단은 독자에게 교재 자체는 물론 교재가 무엇에 관한 것인가에 대한 강한 흥미를 유발시켜 주의집중을 유도할 것이고 더 적극적인 교재처리를 할 것이라는 가정을 기초로 삼고 있다(문선모, 2012). 또한 Mandler와 Johnson(1977)은 이야기 문법은 들어오는 자료 중에서 어떤 측면에 주의를 돌리게 하는 기능을 한다고 했다. 이 연구에서도 아동들에게 이야기 지도를 제시 하여 이해시켰기에 들려주는 이야기를 듣는 중에 관련 구조 요소에 흥미가 더 유발되고 주의집 중이 유도되었을 것으로 유추된다. 아동들은 이야기책에 나오는 색칠한 이야기 그림으로부터 골 라낸 정보를 다시 말하기에 많이 포함시킴을 발견한 Tucker(2001)의 박사논문의 논의로 미루어 보면, 앞에서 언급한 그 유추는 타당한 것 같다.

둘째, 구조 요소별 산출의 개선에 미치는 효과를 구조 요소 간에 비교하면, 해결이 가장 높고, 배경, 순서, 구성, 문제의 순으로 낮았다. 해결, 배경, 순서, 구성 구조 요소 간에는 유의한 차이가 없었고, 이들 4 개 구조 요소는 문제 요소보다 유의하게 높았다. 이런 결과는 이야기 다시 말하기 조건에 관계없이 동일하게 나타났다. 이는 취학전 아동의 경우 이야기 다시 말하기를 가르치면 이야기의 문제 구조 요소 산출의 개선이 가장 힘들었음을 보여준다.

관련 선행연구들을 살펴보면, 단순지시로 접근한 Morrow(1985), 단서제시로 접근한 Greathouse(1991), Tucker(2001), 이야기 문법(구조) 기반 접근을 시도한 Morrow (1986), Kuldanek(1998), Sisco(1992), 그리고 단순지시로 접근한 국내의 반지정(2012), 이강현(2001), 이 수영(2000), 이현지(2005), 하양승(1995) 등의 연구들은 구조 요소 간의 산출의 개선에 미치는 효 과를 검증하지 않아 이 연구결과와 직접 비교할 수는 없었다. 그러나 이야기 다시 말하기로 효과 를 측정하지는 않았으나, 회상효과를 준거로 한 관련 연구들을 살펴보면, 초등학생이나 성인 모 두 주 배경, 시발사건, 결과 구조 요소를 더 잘 회상하고, 초등학생은 주인공의 내적 반응이나 목표 즉 문제 구조 요소를 잘 회상하지 못했다는 Mandler와 Johnson(1977), 초등학교 4학년과 
대학생은 시발사건과 결과 구조 요소를 잘 회상한다는 조혜자(1988), 중학교 학습장애 학생과 정상 학생은 해설, 사건의 계기, 결말 구조 요소를 비슷하게 회상한다는 문선모·임성아(2003) 등의 연구에서 구조 요소별 회상 경향은 이 연구의 다시 말하기 구조 요소별 산출의 개선 경향 과 유사했다. 이야기 구조 요소의 모든 부분이 똑같이 회상되는 것은 아니라는 Mandler와 Johnson(1977)의 주장으로 미루어 보면 이 연구의 결과는 타당한 것 같다.

이 연구에서 이야기의 문제 구조 요소 산출의 개선이 가장 힘든 결과에 대해서는 사전검사와 사후검사에 사용된 이야기책의 성격에서 그 한 이유를 설명할 수 있겠다. 사전검사에 사용된 이 야기책 “금강초롱”에서 문제 구조 요소는 이야기의 앞부분에 제시되었으나, 사후검사에 사용된 이야기책 “금구슬"에서는 이야기의 중간 부분에 제시되었다. 따라서 아동이 사후검사용 이야기 책에서 문제 구조 요소를 인식하기에 어려움이 있었을 것으로 추측된다.

한편, 이 연구에서 구조기반 이야기 다시 말하기 조건이 이야기 다시 말하기 조건보다 이야기 다시 말하기 산출의 개선효과가 더 클 것으로 기대하였으나, 차이가 없었던 것은 아마 사용된 이야기책의 성격에 기인한 듯하다. 즉 사용된 이야기책 “금강초롱”과 “금구슬"은 복잡하지 않은 비교적 단순한 구조로 되어 있었기에 이야기 다시 말하기 조건의 아동들도 이야기 문법 구조 요소들에 주의를 돌리는데 별 어려움이 없을 것으로 생각된다.

끝으로 통제조건에서 특이하게 이야기 다시 말하기 산출의 개선점수가 역(-)의 점수가 나온 것에 대해 설명하기로 한다. 통제조건에서는 이야기 다시 말하기에 대해선 처음부터 아무런 처 치를 하지 않고서 사전검사와 사후검사를 실시하는 것이기에 당연히 두 점수가 비슷하여 개선 점수는 거의 없을 것으로 기대했다. 그런데 역(-)의 점수가 나온 것은 아마 사전, 사후검사용으로 사용한 이야기책의 구성 성격에서 찾아 볼 수 있을 것 같다. 사전검사용 이야기책 “금강초롱”에 서는 이야기 구조 요소로 배경이 제일 먼저 서술되고, 바로 이어 이야기의 문제("누의의 병 고치 기")가 제시되며, 이어서 그 문제의 해결을 위한 시도로서 구성 에피소드들이 7회 계속되었다. 그러나 사후검사용 이야기책 “금구슬”에서는 역시 배경이 제일 먼저 소개되나, 사전검사용 이야 기책과는 달리 문제의 도입으로 시발사건과 구성 에피소드가 3회 계속 된 다음에 문제(“잃어버 린 금구슬 찾기")가 제시되었다. 이어 문제 해결을 위한 시도로서 구성 에피소드가 5회 계속되었 다. 따라서 문제가 무엇인지에 대한 분명한 인식이 힘든 상태에서 이야기를 계속 듣는 것은 이해 를 어렵게 했을 것으로 추정된다. 이런 해석에 대한 한 가지 이론적 근거는 Trabasso와 van den Broek(1985)에서 찾아 볼 수 있겠다. 그들은 성인과 어린이 둘 모두의 경우에, 교재 자료의 회상 은 글의 인과관계의 사슬(causal chain)의 함수임을 밝혔다. 즉 이야기를 읽어주는 상태·사건 - 행위들 즉 이야기 문법 구조 요소들이 인과사슬에 있는 단위가 인과사슬을 벗어난 단위보다 더욱 잘 회상된다고 했다(김지홍·문선모, 2010, p. 285 재인용). 따라서 이 연구의 사후검사용 이 야기책은 사전검사용 이야기책에 비해 문제의 제시위치로 보아 인과사슬이 더 벗어난 것으로 
보인다.

마지막으로, 후속 연구를 위한 몇 가지 제언을 하기로 한다. 이야기 구조의 제시위치를 비슷하 게 통제한 이야기책을 채택하여 검증해볼 필요성이 있겠다. 이야기책의 복잡성을 달리한 비교검 증도 기대된다. 실험 참가자의 연령을 다양하게 하고, 참가 아동수도 늘리고, 이야기책의 종류, 실험처치 기간의 확대 등 연구방법 면에서도 개선하여 심층 검증해 볼 필요가 있겠다. 


\section{참고문헌}

김경희(2004). 그림책 비디오가 유아의 읽기 흥미 및 이야기 다시 말하기에 미치는 영향. 석사학 위 논문, 한국교원대학교.

김지홍, 문선모(역)(2010). 이해: 인지 패러다임 2. 서울: 나남. (한국연구재단 학술명저번역총서 서양편 293). Kintsch, W. (1998). Comprehension: A paradigm for cognition. UK:

\section{Cambridge University Press.}

문선모(1997). 교재학습: 교재구조의 접근. 서울: 학지사.

문선모(2012). 읽기 이해: 교재학습. 서울: 시그마프레스.

문선모, 김은수(2001). 지식지도화 훈련이 교재학습에 미치는 효과. 경남교육학연구, 6, 23-53. 문선모, 임상아(2003). 학습 장애 학생과 정상학생의 이야기 교재 등장인물 정보의 이해분석. 경 남교육학연구, 8, 255-282.

문선모, 전유진(1996). 시각 교재조직자와 교재처리: 이론적 고찰. 학생생 활연구소보(경상대학 교), 22, 37-47.

반지정(2012). 이야기 다시 말하기를 통한 $\mathrm{ADHD}$ 아동과 일반아동의 이야기 산출 능력 비교. 박사학위 논문, 대구대학교.

이강현(2001). 이야기 다시 말하기를 통한 학령기 아동의 의미 및 구문구조 발달에 관한 연구. 석사학위 논문, 대구대학교.

이수영(2000). 이야기책 듣고 이야기 다시 말해보기가 유아의 이야기 구성력 및 문장 이해력에 미치는 영향. 석사학위 논문, 전남대학교.

이현지(2005). 동화를 듣고 이야기 다시 말해보기. 석사학위논문, 공주대학교.

정현조(2012). 읽기장애 아동의 효과적인 읽기 이해 전략에 대한 비교연구: 이야기 다시 말하기, 쓰기. 석사학위 논문, 대구대학교.

조경희, 이정모(1992). 글에서의 대비적 정보처리: 이야기 구조와 표상 위계 수준의 영향. 한국심 리학회지: 실험 및 인지, 4, 76-92.

조혜자(1988). 이야기 구조에 따른 이해 추론 양상. 박사학위논문, 이화여자대학교. 하양승(1995). 유아의 “이야기 해보기" 활동이 이야기 구조 개념과 이해에 미치는 영향. 석사학 위 논문, 이화여자대학교.

홍여찬(2003). 동화 듣고 이야기 다시 말하기 활동이 발달지체 유아의 어휘력 및 이야기 이해도 에 미치는 효과. 석사학위 논문, 공주대학교,

Baumann, J. F., \& Bergeron, B. S. (1993). Story map instruction using children's literature 
effects on first graders' comprehension of central narrative elements. Journal of Reading Behavior, 25(4), 407-437.

Best, D. L. M. (1993). The effects of story retelling opportunities on the second language acquisition of prekindergarten ESL students. Unpublished master's thesis, Tarleton State University.

Brown, H., \& Cambourne, B. (1987). Read and retell. Portsmouth, NH: Heinemann.

Bui, Y. N. (2002). Using story-grammar instruction and picture books to increase reading comprehension. Academic Exchange (Summer), 127-132.

Cleven, J. L. (2005). Training and mentoring childcare providers in story sharing: Effects on vocabulary and story retelling for four-year olds, and story sharing behaviors of childcare providers. North Carolina State University.

Cruze de Quiros, A. M., Lara-Alecio, R., Tong, F., \& Irby, B. (2012). The effect of a structured story reading intervention, story retelling and higher order thinking for English language and literacy acquisition. Journal of Research in Reading, 35, 87-113.

Dansereau, D. F., \& Cross, D. R. (1990). Knowledge mapping: Cognitive software for thinking, learning, and communicating. Department of Psychology, Texas Christian University. Davis, Z. T., \& McPherson, M. D. (1989). Story map instruction: A road map for reading comprehension. The Reading Teacher, 43, 232-240.

Gambrell, L. B., Koskinen, P. S., \& Kapinus, B. A. (1991). Retelling and the reading comprehension of proficient and less-proficient readers. Journal of Educational Research, 84(6), 356-362.

Genishi, C., \& Dyson, A. H. (1984). Language assessment in the early years. Norwood, NJ: Ablex. Geva, E., \& Olson, D. (1983). Children's story retelling. First Language, 4, 85-109.

Greathouse, N. J. (1991). The effects of retelling stories on comprehension and the language growth of kindergarten children. Unpublished doctoral dissertation, Indiana Sate University.

Hansen, J. (2004). "Tell me a story": Developmentally appropriate retelling srategies. Newark, DE: Internaltion Reading Association.

Hayward, D., \& Schneider, P. (2000). Effectiveness of teaching story grammar knowledge to preschool children with language impairment: An exploratory study. Child Language Teaching and Therapy, 16(3), 255-284.

Huston, J., \& Shapiro, L. (1991). From knowing to telling: The development of children's scripts, stories, and personal narratives. In A. McCabe \& C. Peterson (Eds.), 
Developing narrative structure (pp. 89-136). Hillsdale, NJ: Erlbaum.

Isbel, R., Sobol, J., Lindauer, L., \& Lowrance, A. (2004). The effects of storytelling and story reading on the oral language complexity and story comprehension of young children. Early Childhood Education Journal, 32(3), 157-163.

John, C. F. (2001). Story retelling and attention deficit hyperactivity disorder. Unpublished master's thesis. University of Toronto.

Johnson, R. T. (1988). Retelling: A strategy for enhancing students' reading conference. The Reading Teacher, 41(9), 892-896.

Koskinen, P. S., Gambrell, L. B., \& Kapinus, B. A. (1989). The effects of rereading and retelling upon young children's reading comprehension. In McCormick \& Zutell (Eds.), Thirty-eighth Yearbook of the National Reading Conference Chicago, IL: Reading Conference.

Kuldanek, K. (1998). The effects of using a combination of story frames and retelling strategies with learning disabled students to build their comprehension ability. Unpublished master's thesis, Kean University.

Mandler, J. M., \& Johnson, N. (1977). Remembrance of things parsed: Story structure and recall. Cognitive Psychology, 9, 111-151.

Morrow, L. M. (1985). Retelling stories: A strategy for improving young children's comprehension, concept of story structure, and oral language complexity. The Elementary School Journal, 85, 647-661.

Morrow, L. M. (1986). Effects of structural guidance in story retelling on children's dictation of original stories. Journal of Reading Behavior, 18, 135-152.

Morrow, L. M. (1996). Young children's responses to one-to-one story readings in school settings. Reading Research Quarterly, 23(1), 89 -107.

Sisco, L. J. (1992). The effects of mediated story retelling on the development of listening comprehension, story structure and oral language in young children with learning disabilities. Unpublished doctoral dissertation, The State University of New Jersey.

Spencer, T. D. (2009). The effect of a narrative intervention on preschoolers' to retelling and personal experience story generation skills. Unpublished doctoral dissertation, Utah State University.

Stein, N. L., \& Glenn, C. G. (1979). An analysis of story comprehension in elementary school children. In R. O. Feedle (Ed.), New directions in discourse processing (Vol. 2, pp. 53-120). Norwood, New Jersey: Ablex. 
Thorndyke, P. W. (1977). Cognitive structures in comprehension and memory of narrative discourse. Cognitive Psychology, 9, 77-110.

Trabasso, T., \& Van den Broek, P. (1985). Causal thinking and the representation of narrative events. Journal of Memory and Language, 24, 612-630.

Tucker, R. (2001). Story retelling: The effects of guided practice on kindergarten children's ability to retell stories. Unpublished doctoral dissertation, University of Pittsburgh.

Westerveld, M. F. (2010). Oral narrative context effects on poor readers' spoken language performance: Story retelling, story generation, and personal narratives. International Journal of Speeh-language Pathology, 12(2), 132-141.

Zanowicz. M. (1996). Story retelling effects. Unpublished master's thesis, Kean College of New Jersey.

* 논문접수 2013년 11월 4일 / 1차 심사 2013년 12월 10일 / 2차 심사 2014년 3월 4일 / 게재승인 2014년 3월 10일

* 문선모 : 계명대학교 교육학과를 졸업하고, 경북대학교 대학원 교육학과에서 교육심리전공으로 석사학위와 박사학위를 취득하였다. 현재 경상대학교 사범대학 교육학과 교수로 재직 중이다. 주요 저서로는 '교재학습 연구: 교재구조의 접근', '읽기 이해: 교재학습, '학습이론: 교육적 적용', '교육심리학: 학습 · 발달 중심 접근' 등 9권이 있다. 주요 역서로는 '인간 기억 및 인지 연구방법론', '중심내용의 이해와 수업', '이해: 인지 패러다임 1 · 2', '실험설계 및 통계의 기초' 등 14 권이 있다. 그리고 Kintsch 모형으로 연구한 박사학위논문 《교재구조의 거시방략과 거시명제의 회상》 (1985)이 있다.

*E-mail:smmoon@gnu.ac.kr

* 최의경 : 한국국제대학교 사회복지학과를 졸업하고, 한국국제대학교 대학원에서 사회복지전공으로 석사학위를 취득하였으 며, 경상대학교 대학원에서 교육심리전공으로 박사학위를 취득하였다. 현재 경상남도 진주시 에덴어린이집 원장으로 재직 중이며, 경상대학교와 경상대학교 교육대학원의 강의를 맡고 있다.

*E-mail: cek5824@hanmail.net 


\title{
Effects of Conditions of Story Retelling on the Improvement of Story Retelling Production in Preschool Children
}

\author{
Moon, SeonMo* \\ Choi, EuiKyung ${ }^{* \star}$
}

The purpose of this study was to investigate the effects of conditions of story retelling on the improvement of story retelling production in preschool children. For the purpose three conditions of story retelling were treated: (1) story retelling condition which children were trained to retell with gently probing, (2) story structure-based story retelling condition which children were trained to retell both with guiding questions on story structures and with teaching story mapping emphasizing elements of story structure, and (3) control condition which children were not received such training. In the experiments a mixed, between-subjects, within-subjects, design was used. One between-subjects variable was conditions of story retelling (story retelling - story structure-based story retelling $\cdot$ control). One within-subjects variable was testing time (pre $\cdot$ post). The criterion variables were scores of difference score between pretest and posttest in total production and individual elements production of story retelling. Participants were 27 children, age 5 years, selected from one preschool and were assigned randomly to three conditions. These children were received six sessions which consisted of one pretest, four training and one posttest. And six storybooks were used for story retelling. Both story retelling condition improved total production and individual elements production of story retelling. The improvement in the production of individual elements of story structure were different significantly between resolution, setting, order, plot, and problem elements. These differences in the improvement showed similar trends regardless of story retelling conditions.

Key words: story map, story retelling, story retelling production, story structure

** Director, Eden Nursery 